\title{
PARANA PINE AND EUCALYPTUS IN BRAZIL'
}

\author{
By R. G. RAY
}

During a visit to Brazil in March-April 1952, I met several Brazilian foresters, saw the Klabin pulp and paper mill at Monte Alegre, and exhibits of the Paulista Railway Company eucalyptus at Rio Claro and of the Sao Paulo State Forest Service at Cantareira. Although I spent only three days visiting, I spent considerably more in making arrangements, calling upon people, travelling and collecting literature.

Most of the recent forestry literature is included in the "Annual of Brazilian Forest Economy" published by the National Pine Institute since 1948; No. 3, 1950 is the latest one available. They contain some very interesting articles and technical papers on forestry and forest products, (in Portuguese, with English summaries), and the statistical section covers the entire forest industry pertaining to production, export trade and to forest products from other countries.

Some aspects of Brazilian forestry are most impressive and easy to see. Nevertheless, after such a short visit it would be impossible to write a comprehensive report based upon my own observations. An attempt to fill in the background of what I saw and to correlate it with conditions prevailing in the country has been made by references to this literature.

The inclusion of Brazil in technical assistance programs, and the establishment of the F.A.O. regional forestry office in Rio de Janeiro, might exaggerate the impression of the country's needs. Brazil certainly needs capital and technicians, but in any such association the interchange of ideas would be by no means one sided. Brazilians are evidently quick to profit from others' experience and the technique which they have developed might well deserve attention in other countries.

Forest operations in the natural stands of the Brazilian forest are mostly confined to clear cutting and burning off to provide for agriculture, or else to exploit the valuable species regardless of consequences. The forest land within the developed southern part of the country is shrinking rapidly and this has led to the planting of eucalyptus and to certain conservation measures for pine.

Brazil, with a population of only 50 million, is larger in area than the U.S. and the greatest part lies within the tropics. Only that part south of Sao Paulo is sub-tropical, the Tropic of Capricorn lying one mile north of the city. Consequently the much smaller range in climate tolerates uniform conditions throughout whole regions and it is therefore easier to see representative areas of Brazil than of the U.S. in spite of the size of the country. Furthermore the principal developments in industry and agriculture are concentrated in the comparatively small area southwest of Rio de Janeiro and northwards in a narrow band along the coast.

The forest area, approximately $1,530,000$ square miles (1) or just over $46 \%$ of the total area of the country, is mostly in the Amazon region which has hardly been developed and offers tremendous difficulties in trans1 This paper was prepared subsequent to a visit to the states of Sao Paulo and Parana, March 27, 28 and April 3, 1952. 
portation, climate, jungle, and living conditions for any but the natives. Besides, much has to be done in the more settled parts to solve the social and economic problems which beset the country before efforts can be expended in this difficult and remote territory.

In spite of its enormous wealth in agriculture and industry, the country lacks the basic energy sources of coal and oil. Abundant hydroelectric power serves Rio de Janeiro, Sao Paulo and vicinity through the ingenious method of pumping over a low height of land to a high head, and potential hydro-electric power is tremendous, but as the rivers rise fairly near the coast and flow west and south towards the interior, the power sites are mostly far removed from present centers of industry and are therefore undeveloped. Although we may hear much about Brazilian coffee, nuts and a few other items, fuelwood and wood products are also of great importance in the economy of the country.

Most Brazilian exports are raw materials or only partly manufactured and therefore a huge volume of commodities has to be moved to purchase machinery and other technical products from abroad, particularly in the United States. By 1947 wood had risen to third place according to value in Brazilian exports, $75 \%$ of which was pine. These bulky products place a severe strain upon the transportation facilities, which are quite inadequate for the rising needs of the country. The railways lack rolling stock and are poorly maintained, modern highway construction is just beginning and water transportation does not exist because, as mentioned above, the rivers flow the wrong way.

Brazil produced approximately as much wood as Canada in 1950, 94 million cubic meters, and thus ranks next to the U.S. and Russia in world production. Total exports were in the same year 925,000 cubic meters which is less than $1 \%$ of the total production, and points to an unusually large proportion of output reserved for domestic consumption. The total production of pine was $3,328,000$ cubic meters of which 818,000 cubic meters were exported.

By far the greater part of the domestic demand is in fuelwood for cooking and heating, power development, and the wood burning locomotives. The railways use over twice as much fuelwood as coal and although electrification of some main lines is proceeding, new branch lines are being built and little reduction in fuelwood demand can be foreseen at present.

Depletion of the accessible forest for fuelwood is already causing concern as shown by Pinto de Souza (4):

"We must therefore proceed at once to restore our forests, if we de not want to destroy the only source of energy we possess.

"Among other measures, we shall have to reduce our consumption of firewood for cooking. This may be reduced to a fifth of what it now is by using gasogene apparatus, which would also produce similar results in industrial plants.

"So far, no country in the world adopted firewood as a basic fuel; they all depend on coal. Firewood, however, produces the ideal type of 
metallurgic coke. If we develop and utilize our woodland wealth in the right way, husbanding our store of firewood, we shall be able to compete with and even, in certain circumstances surpass the coalproducing countries".

Thus, wood is admittedly the main source of power or energy and they have to make the best of it. Liberal land grants in the early days of colonization have alienated practically all the accessible forest and now less than $4 \%$ belongs to the state. Forest conservation cannot be achieved by government regulation without encroaching upon private rights-which they are loath to do-and therefore it will depend more upon education and cooperation on the part of all concerned.

Brazil is a country of contrast in many of its ways of life. On the one hand it contains one of the world's greatest forest resources, on the other hand symptoms of approaching timber famine are already showing; highly intensive reforestation, developed over many years and practiced with extraordinary skill with eucalyptus (and latterly with pine), proceeds along with forest devastation from land clearing and complete disregard of the precarious situation the country would be in if wood production were seriously curtailed. The immediate problems of transportation and mechanical equipment are so pressing however that silviculture and long term forestry cannot yet fill their rightful place in the national economy.

Construction of office buildings, 12-14 storey apartment houses, factories and public works is proceeding in the large cities, and real estate values are bounding upwards, all of which supplies ample evidence of the tremendous boom now in progress. Private enterprise coupled with high incentives operating under a stable government provides the driving force and the results are impressive. There is a tendency for joint efforts between the state and private concerns to solve national problems, instead of by nationalization. One example is the National Pine Institute which is financed by both the State and industry and functions independently under the jurisdiction of the Federal Government, with control over the pine industry.

PARANA PINE

While there are some plantations of pine in the vicinity of Sao Paulo, I was told that one had to visit Parana to see this species in its natural habitat. Accordingly, I flew from Sao Paulo to Curitiba, capital of the State of Parana, some 200 miles distant, and presented my letters of introduction to the Chief of the District Office of the National Pine Institute.

Curitiba lies 50 miles inland on a plateau 3,000 feet above sea level, which drops abruptly to the sea. Flying from Sao Paulo gives one an excellent view of the coastal range, Serra do Mar, which follows the coast for the better part of the length of Brazil, with peaks rising to over 4,000 feet. This high ground tilts off to the west from the foothills, which are very broken and extend some 30 miles inland, through gently rolling country interrupted occasionally by broad valleys and long ridges down to the Parana river, about 400 miles from the coast. The soil is rich but difficult to cultivate because the hills are so steep and the country is so 
broken up. The underlying formation, as I saw later, is a soft sand-stone, the soil is dark red near the coast and very deep, but becomes grey inland and along the high elevations where the soil is poorer and devoid of forest. Hard solid rock and boulders are evidently rare, for all the road cuts I saw were through the same sort of material, tightly compressed but easily moved with a bulldozer.

Throughout the pine region the climate varies from tropical in the northwest with heavy rainfall to sub-tropical in the southeast where frost occurs in season. In general, rainfall ranges between $51^{\prime \prime}$ and $74^{\prime \prime}$, and the average mean annual temperature between $59^{\circ} \mathrm{F}$. and $63^{\circ} \mathrm{F}$.

Parana pine, known also as Brazilian pine, (Araucaria angustifolia, (Bert O. Ktze) or A. Braziliana) is a distinctive feature of the landscape in the State of Parana. The only coniferous tree of note in Brazil, it occurs in the states of Parana, Santa Catarina, Rio Grande do Sul, and more rarely in Sao Paulo. Beautifully symmetrical, with a cylindrical trunk clear of branches, this tree curves its branches upwards and ends when mature in a perfectly level flat top almost the full width of the branches themselves. Single specimens have been known to reach 160 feet in height and about 40 inches in diameter, but the usual dimensions are 60 to 90 feet and 20 to 35 inches (1). On grass lands it may be scattreed with clear ground underneath but in the forest it usually comprises a complete top storey with an understorey of broad leaved species. It also grows in mixtures with other species. In these three broad types it occurs throughout an area of approximately 100,000 square miles, perhaps one quarter of which might be classed as forest.

The fruit is a cone and each seed is about 2 inches long, edible and much prized by the aborigines. Pine is an intolerant species; the seedlings cannot overcome the underbrush nor the broad leaved trees with which they must compete, and natural reproduction is very poor except along roadsides and at the edge of a stand (1). The wood has annual rings although there are doubts as to whether these are fully reliable indicators of age.

Continuing by bus 60 miles from Curitiba to Ponta Grossa, an important railway junction through which most of the products of the state pass on the way to market, I met the local forester of the Pine Institute who was to be my guide, Mr. Ernesto Araujo, but he knew very little English. Fortunately, I had met a Dutch agriculturist who spoke English and Portuguese fluently and prevailed upon him to accompany us next day to the pulp and paper mill at Monte Alegre (Industrias Klabin do Parana) 170 miles inland. We drove about four hours each way over winding gravel roads, mostly in open country with patches of cut-over pine forest and I saw no signs of any reforestation on the way.

Built in 1944, the mill produces 100 tons of newsprint per day, 60 tons of pulp and 40 tons of cardboard, working a 7 day week, day and night. The plant is being enlarged to accomodate a second newsprint machine.

Mechanical pulp made from pine is said to be superior to imported 
because the fibres are stronger, but the pulp is not as clear; sulphite pulp is as good as imported, kraft is superior and newsprint is quite satisfactory except that the surface is slightly rougher (1). A hydro-electric development nearby supplies more than enough power, but fuelwood is used for generating steam for the driers and digesters, and fuelwood requirements equal the pulpwood which are 275 to 315 cords ( 700 to 800 cubic meters) per day. The mill now supplies $40 \%$ of Brazil's newsprint. The railway branch line to the mill was completed recently and a modern highway will soon connect with the super highway to Sao Paulo, also under construction. The present roads are winding and unsurfaced.

The company holdings of 620 square miles $(160,000$ hectares) of forest are being actively exploited and a considerable quantity of wood is also purchased from private owners. Because future supplies are uncertain and becoming more and more remote, a large scale program of reforestation has been put into effect. Plantations begun in 1946 and expanded two years later now cover $30-40$ square miles $(8,000$ to 10,000 hectares), planted with 40 million trees. Some eucalyptus is also being planted for fuelwood and possibly for pulp.

Reforestation procedure is quite extraordinary. Pine will not stand transplanting, consequently the seed is sown in location. Each seed is simply laid horizontally on the ground at intervals of 2.5 feet in rows 4 feet apart. (.8 81.2 meters). The ground must first be cleaned, then ploughed and harrowed, and the plantation must be cleaned of weeds for two years after planting. Cleaning is done by hand usually at the rate of 200 cruzeiros per hectare (approximately $\$ 2.70$ per acre) and one man can clean approximately half a hectare per day.

As long as labour is cheap this reforestation procedure is quite practical and the total cost, said to be 6,000 cruzeiros per hectare ( $\$ 81$. per acre) including cost of land but not administrative overhead, is very reasonable compared to the probable returns. The 6 year old plantation I saw was 10 to 12 feet in height and the trees were 2 to 3 inches in diameter. Mortality is about $15 \%$.

I saw nothing of the woods operations because they occur some distance from the mill and due to a misunderstanding my visit was limited to one day. The wood is cut into pulpwood lengths, (approximately 4 feet), peeled and split in the woods, then trucked to the mill. Handling an equal volume of fuelwood is a tremendous amount of work, but labour in that part of the country is plentiful and cheap. Wages at the mill are as high as in any other industry of the region and, at that, unskilled labour receives only 4 to 5 cruzeiros (13c to $14 \mathrm{c}$ ) per hour without board or lodging, skilled labour 11 cruzeiros maximum (36c) and double time for working on Sundays and holidays. (Conversion rate 30 cruzeiros to 1 dollar.)

The whole operation is new and undoubtedly many difficulties have yet to be solved both in the mill and in the forest. Pine silviculture is in its infancy; the oldest plantation in the country is only 25 years old, and knowledge of pine even in its natural state is far from complete. Ac- 
cording to yield tables prepared from sample plots in plantations (3), a mean annual increment of 215 cubic feet per acre (15 cubic meters per hectare) is possible at least for the first 23 years. Net yields at 20 years are given as: 3,500 cubic feet per acre for site I; 2,650 cubic feet for site II, and 1,580 cubic feet for site III.

Present plans call for cutting after 15 years, but unless profit lies in cutting a great many small sized trees this will probably be a partial cutting. If experience in Australia with another species of Auracaria, Cunningbamii, is a criterion (2), the rotation age would more likely be 30 years and certainly not more than 50 . On the other hand, the old growth wood I saw in the mill, if the annual rings are correct, showed a growth rate no faster than in our own softwoods.

One thing is reasonably sure, the accessible mature pine will be finished in the not too distant future at the present rate of exploitation. Reforestation as a public effort is still unknown. With the exception of the Klabin Company, the National Pine Institute is the only organization carrying out reforestation, and it is still on a comparatively small scale. The farmer and the saw mill operator are as yet taking no part whatever except in the cutting and selling.

Anyone contemplating woods operations on a large scale in Brazil must be prepared to carry out silviculture and reforestation, not only because it is required by law of all major wood using industries, but to assure future supplies. On the other hand, the climatic conditions are so favourable and the growth in plantations is so rapid that highly encouraging results will certainly be obtained within a short time.

As mentioned before, one serious drawback in the Brazilian economy is inadequate transportation. For example lumber is hauled by truck to Sao Paulo, a distance of 400 to 500 miles simply because the railway cannot cope with it.

Pine lumber is being dumped in the dollar markets and sold at high prices in others to raise foreign exchange to purchase equipment for transportation and other industries. This hardly promotes the stable atmosphere necessary for the practice of silviculture. It is hoped that the country's economy will be balanced before all these beautiful pine forests will have been destroyed in the process, but without adequate transportation and equipment not even Brazil with all its advantages in climate, soil and markets can progress very far with forest management, still less with silviculture.

\section{THE NATIONAL PINE INSTITUTE}

Reference has been made to the necessity for forest conservation and also to the lack of many facilities for operating and exploiting timber lands. Something had to be done to establish the pine industry upon a sound foundation. As the Brazilian Government refrains from interfering with private enterprise any more than necessary, a separate organization, the National Pine Institute, was formed in 1941 to be an "organ in the interests of producers, manufacturers and exporters of pine". 
The Institute comes under the jurisdiction of the Department of Works, Industry and Commerce and consists of a president and a council of eight members, four of whom represent the Government and four the wood using industry. Regional councils and regional offices are established throughout the pine region. Thus the Institute combines the authority of government with the business and technical skills of private enterprise to organize this most important industry, including the gathering of all statistics. Its activities are self supporting through a special sales tax levied upon all pine products.

According to their statement of policy, the functions of the Institute cover every phase of growing, marketing, producing, manufacturing, reforestation, price fixing, export quotas, and promotion of forestry in other species. The following principles were adopted in the policy statement drawn up in 1950: (8)

"In its mission as a semi-state organization authorised to promote and maintain an even balance and perfect harmony between the interests of the public in general and those of the lumber trade, the "Instituto Nacional do Pinho" adopted on December 19th, 1949, eight guiding principles which came into force on January 1st, 1950 constituting the lines along which the Brazilian economic policy regarding the timber trade is conducted".

1. Preservation of the forest reserves in a measure which assures a continuous supply of the raw materials which are derived therefrom.

2. Promotion of the production of the materials by means of afforestation (plantations).

3. Maximum utilization of the trees cut.

4. Progressive industrialization of forest products, preferably at the source of production itself.

5. Expansion of markets (consumers).

6. Balance between production and consumption by the control of both.

7. Tendency toward liberty of initiative in the wood trade.

8. Social wellbeing for all workers in the field.

In order to "promote reforestation of cut-over areas and encourage forestry education in the wood-producing centers", (9) the Institute maintains eight forestry stations: one in Sao Paulo, two in Parana, one in Santa Catarina, three in Rio Grande do Sul and also one in Minas Gerais, in the extreme northern range of pine.

Research in pine seeding and planting is carried on and they may also acquire land for planting. The area of all stations combined (1950) is 29,320 acres or 45.7 square miles. Since then nearly $20,000,000$ pine have been planted in part of this area. A total of 5,550 acres has been planted to 1952 in the two stations in Parana. Half the revenue of the Institute is supposed to be spent upon reforestation.

\section{EUCALYPTUS}

About the same time as the native rubber tree from the Amazon was being adapted to culture in Malaya, eucalyptus from Australia was being 
transplanted in Brazil, with outstanding results. In 1904, Dr. Edmundo Navarro de Andrade, newly appointed "Director of the Forest Farm" for the Paulista Railway Company, began his experiments with eucalyptus and many other species both native and exotic (6). The eucalypts proved the fastest growing and were therefore given preference in the other "forest farms" which were eventually established on the lands owned by the railway company.

Since then over 150 species of eucalyptus from all parts of Australia have been tested and about 15 different species have proved successful for the various purposes for which the wood is required. Dr. Navarro de Andrade died in 1941 after having established 17 forest farms for the railway company and having built up a complete forest service. This is now headed by his nephew, Armando Navarro Sampaio, with headquarters at Rio Claro, 110 miles west of Sao Paulo.

Unlike most of the railways in Brazil which operate at a loss, and lack equipment and maintenance, the Paulista Railway is one of the best anywhere. I could believe this after travelling very comfortably from Sao Paulo to Rio Claro in modern first class Pullman and dining cars over a smooth road bed, with no wheel noise because the rails are laid in 200 meter lengths with welded joints. The main line is mostly electrified and new General Electric engines haul the train at 60 miles an hour and more. The Company has about a thousand miles of track.

The country is rugged for the first 30 miles out of Sao Paulo, then it breaks into rolling country, with wide valleys and plains, and I noticed many eucalyptus plantations on the way. I was taken to lunch by Dr. Navarro Sampaio, shown over the forestry station in the afternoon, and returned to Sao Paulo the same evening.

It is apparently the custom in Brazil (one of many examples of their hospitality) to assemble forestry exhibits in a museum. Rather than drag visitors into the snake infested jungle (so we foreigners are inclined to believe) they put up a beautiful building and arrange the most elaborate and complete exhibits. This is what has been done in Rio Claro and also by the Sao Paulo State Forest Service at Cantareira, a mile out of Sao Paulo. There was so much to see in the museums that I spent the afternoon in each and consequently had no opportunity to see more than the beautiful grounds in the vicinity.

Both these museums defy description. For completeness and artistic presentation they are perhaps unexcelled, certainly no other forestry exhibit can compete. At Rio Claro, all the woodwork is eucalyptus. Each plank of the floor in the main hall is of a different species of eucalyptus; the tables, chairs and other beautifully made furniture are also of eucalyptus. Samples of the important species of eucalyptus carved to resemble books are arranged on a shelf, with one sample finished, another plain, and each one numbered to identify the species. Statistics from 1904 to 1948 showing the developments in eucalyptus plantations are on the walls; racks with illuminated coloured slides on ground glass show the stages of collecting seeds, transplanting and planting eucalyptus; live specimens of all the fish 
in the nearby lake are kept in an aquarium; stuffed specimens of the birds and animals found in the plantations are mounted; and then there are the buildings for the forestry staff including a splendid house for the Director all in a setting of beautiful palms and avenues of eucalyptus with a small lake in the background. Samples of railway ties and telegraph poles which have been in position for a stated number of years with and without treatment, and $\log$ sections of the largest eucalyptus trees grown to date are kept on view in a shed nearby. All sorts of hand tools and implements carved from eucalyptus are also shown, and another exhibit displays the various products made from the oil extracted from the leaves, including a foreign made cure-all lotion guaranteed, among other things, to make the hair grow!

The railway companies and other wood using industries which have been granted lands are obliged by the government to carry on reforestation. The Paulista Railway Company forestry department is of first rate importance in the operation of the railway and now supplies $30 \%$ of their wood requirements. This comprises ties, telegraph poles, planking for stations and freight cars, and fuelwood for the wood burning locomotives which operate on the branch lines of the railway system.

The plantations now cover 61.8 square miles $(16,000$ hectares) with a total of $38,000,000$ eucalyptus trees. These are on lands granted to the Company during its period of construction and the land planted is either marginal or unfit for agriculture. The annual yield of 106,000 cunits ( 300,000 cubic meters) is obtained in a rotation of 8 years, and the total requirements are 353,000 cunits $(1,000,000$ cubic meters) most of which is fuelwood. All railways in Brazil are having a difficult time, the Paulista included, and although planting continues the plantations are being temporarily overcut.

After much experimenting in planting, the best spacing has been determined at $2 \times 2$ meters and the economic rotation age at 8 years, in which time the trees reach 10 to 14 inches in diameter and 80 to 90 feet in height. The plantation is then clear cut and allowed to grow again from sprouts. This operation can be repeated for four rotations after which the stock deteriorates and it is considered more economical to replant. Certain plantations may be left to grow longer for large dimension timbers; some of the trees will then reach a diameter of 3 feet in 30 years and 4 feet in 40 years with a height of at least 100 feet.

Tropical soils generally are slow to absorb nutrients and consequently these are washed down to bed rock quite rapidly with the heavy rainfall. After the forest has been removed, leaf litter no longer releases these nutrients and therefore tree roots penetrate deep into the ground in search of them (5). I was told that many of the eucalyptus trees extend as far underground as above which would mean their roots penetrate to a depth of 90 feet in some places; also that the soil is lacking in calcium.

It seems strange that none of the hundreds of native species can approach the eucalyptus for rapid growth, but it has been proved that eucalyptus will reach a certain size in half the time taken by the fastest 
growing native tree, and the wood is quite satisfactory. The luxuriant tropical forest might at least be expected to provide fuelwood more readily than a plantation, but it cannot compete either. The average natural stand of forest contains about 2,900 cubic feet per acre (200 cubic meters per hectare), whereas eucalyptus at 7 years might contain as much as 4,300 cubic feet per acre (300 cubic meters per hectare). Specific examples of yields from measurements in the plantations with $2 \times 2$ meter spacing are as follows:

\begin{tabular}{ccc} 
Species & $\begin{array}{c}\text { Age } \\
\text { Years }\end{array}$ & $\begin{array}{c}\text { Volume } \\
\text { C.F./Acre }\end{array}$ \\
\hline Eucalyptus alba & 7 & 3,630 \\
Eucalyptus saligiza & 8 & 3,930 \\
Eucalyptus saligna & 10 & 5,510
\end{tabular}

The rotation age has to be carefully calculated because one year makes a great difference; 7 years is possible but to be on the safe side the policy is to allow 8 years.

The economics of growing eucalyptus depend upon how this species can compete with natural forest and with coal. One ton of imported coal worth 1,000 cruzeiros is equivalent to 8 cubic meters of wood worth 400 cruzeiros, therefore coal costs $21 / 2$ times as much as fuelwood. As for production, the average cost (including land value) of one tree 7 years old is 6 cruzeiros; with an average of 8 trees per cubic meter, this gives a value of 48 cruzeiros per cubic meter.

The fact that the Company is such a big user and produces so much of its own wood permits it to set the purchase price along the railway line and a further saving may thus be indirectly credited to the forestry department. The price paid is 50 cruzeiros per cubic meter whereas other industries without their own wood pay 80 and the price in Sao paulo is 100 cruzeiros. However, at 50 cruzeiros per cubic meter not much profit is left for the grower. Nevertheless, the extent to which eucalyptus is being planted may be judged from the fact that $50 \%$ of the purchased wood is also eucalyptus.

The Paulista Railway Company has built up and maintained a forest service which would be a credit to any government, let alone a private company. It includes separate management, technology, entomology and genetics sections, all staffed with highly trained personnel.

The management section takes care of the working plan, silvicultural operations, records and maps which are complete for each parcel of land. Studies to improve the yield, quality and refinements in planting methods are still in progress.

The technology section tests wood of the different species for the various purposes required by the railway and they have their own saw mills at or near the larger forestry stations. Eucalyptus checks badly therefore the procedure is to saw a narrow board out of the center of each $\log$ to eliminate the worst part, with a railway tie cut from each side. 
The wood loses approximately $50 \%$ of its weight in six months' air drying after felling. Untreated railway ties are good for only 7 years. Various wood preservatives are being used and tested, but creosoting is too expensive. The by-products of industries from which creosote is made are unfortunately lacking in Brazil. Experiments are being carried out in the manufacture of pulp from eucalyptus and a small test plant has been set up capable of producing 400 kilos of pulp in 24 hours.

The entomology section has collected specimens of the noxious insects and the staff is on the alert for insect epidemics. So far none have occurred in the company plantations, but they have elsewhere. As soon as an outbreak is reported the infested areas will be dusted by aircraft.

The genetics section, organized recently by Mr. Sampaio, continually strives for improvements, with more emphasis upon tree selection and crossing than upon testing more exotics from Australia. This work proceeds comparatively quickly, because the size of the seedling at six months has proved to be a true indication of its success in later life. In other words if it does not attain a certain height by that time its limitations are known. It has been learned from experience that trees from a certain latitude in Australia give best results when planted in the same latitude in Brazil. Species which are widely represented throughout Australia give the best results, hence species of uncommon occurrence are eliminated. In spite of attempts to propagate eucalyptus by cuttings, only one has succeeded and the tree is still growing at one of the experimental stations.

The genetics section is entirely self supporting through the sale of eucalyptus seed. Ordinarily seed sells for 60 cruzeiros per kilo, but when seed is collected from elite trees, and guaranteed for 2 or 3 generations, it sells for 200 cruzeiros per kilo. As one and a half tons of seeds are sold a year, the added revenue is substantial.

This is indeed forestry very highly developed, completely integrated with industry and an example which would be difficult to match anywhere.

\section{REFERENCES}

1. AUBREVILLE, A. The pine forests of Brazil. Annual of Brazilian Forest Economy, National Pine Institute, Vol. 2, 1949, pp 21-36.

2. GILMOUR, J. D. Summary of talk on visit to Australia and New Guinea, April-July 1951 to Quebec Section C.I.F., Dec. 18, '51.

3. KISSIN, I. Growth and yield of Brazilian pine. Annual of Brazilian Forest Economy, Vol. 3,1850 , pp $429-477$. 4. PINTÓ DEE SOUZA, A. Firewood as a basis for industrial progress. Idem Vol. 3, Dp

5. RAWITSCHER, F. The problem of Brazilian savannas and savannas in general. Idem Vol. 3 , pp $33-38$

6. SAMPAIO, A. Navarro. Edmundo Navarro de Andrade: a narration of bis life and work. Idern Vol. 2, pp 51-53.

7. Idem Vol. Description of the methods of eucalyptus cultivation of the Paulista Railway foreat 8. The policy adopted 1947 .

8. The policy adopted by the Inst

9. The reforestation service of the I.N.P. Idem Vol. 2, pp 403-411. 